\title{
Mental mapping strategy in educative process and the quality of pupil's learning performance
}

\author{
[Strategia mentalneho mapovania $\mathrm{v}$ edukacnom procese a kvalita \\ ucebneho vykonu ziaka]
}

Jana Duchovicova - Rebeka Stefania Kolenakova

DOI: $10.18355 /$ XL.2018.11.02.43

\begin{abstract}
The study deals with the key psychodidactic topic - the optimization of mediation in educative process using the knowledge on intelligence, cognition and processing of information in the form of mental representations. In the presented study, the optimization strategy is mental mapping applied to educative processes in primary education in the field of language and communication and nature and society. The subject of the study is to identify the impact of mental mapping strategy on pupils' learning performance. The learning performance is operationalised at the factual, conceptual and procedural knowledge level and the study design is based on a pedagogical experiment. The results of the study indicate that the pupils reach higher level of learning performance when the mental mapping strategy is applied in educative process.
\end{abstract}

Key words: psychodidactics, mental mapping, learning performance; factual, conceptual, procedural knowledge, mental maps

\begin{abstract}
Abstrakt
Štúdia sa zaoberá kl'účovou psychodidaktickou témou, ktorú predstavuje optimalizácia sprostredkovania vo vyučovaní využívajúca poznatky o myslení a inteligencii, o kognícii a spracovaní informácií v podobe mentálnych reprezentácií. Stratégiou optimalizácie v predmetnom výskume je mentálne mapovanie, ktoré je aplikované $\mathrm{v}$ edukačnom procese $\mathrm{v}$ primárnom vzdelávaní $\mathrm{v}$ témach vzdelávacích oblastí jazyk a komunikácia a príroda a spoločnost'.

Predmetom skúmania je identifikácia vplyvu stratégie mentálneho mapovania na učebný výkon žiakov. Učebný výkon je operacionalizovaný v rovine faktických, konceptuálnych a procedurálnych poznatkov žiakov a výskumný dizajn je založený na pedagogickom experimente. Výsledky výskumu dokazujú, že žiaci, u ktorých je vo vyučovaní aplikovaná stratégia mentálneho mapovania dosahujú vy̌̌šiu úroveň učebného výkonu.
\end{abstract}

Kl'účové slová: psychodidaktika, mentálne mapovanie, učebný výkon, faktické, konceptuálne, procedurálne poznatky, mentálne mapy

\section{Úvod}

Moderná súčasná škola, činná škola 21. storočia alebo škola pre život sú len niektoré zo synoným, kam by mala súčasná škola smerovat'. V posledných rokoch môžeme vidiet' rastúcu kritiku spôsobov, postupov, metód a stratégií, prostredníctvom ktorých pedagógovia svojim žiakom sprostredkúvajú obsahy alebo učivo. Stále pretrvávajúce a realizujúce sa tradičné spôsoby vyučovania $\mathrm{v}$ školách nie je možné eliminovat', no moderná filozofia edukácie sa o to intenzívnejšie zameriava na procesuálnu, tvorivú, činnú a kognitívnu koncepciu vyučovania, ako na cestu k efektívnejšej výučbe. Učitelia si na jednej strane môžu položit' otázku, ako správne a efektívne vyučovat' a na druhej strane chcú žiaci vediet', aké sú ich možnosti naučit' sa učivo čo najrýchlejšie a najefektívnejšie. Podl'a S. Sveca (1995) pojem l’udské učenie predstavuje proces rozvojovej modifikácie vedomostí, schopností, postojov a iných 
vlastností osobnosti človeka, ktorá sa prejavuje v zmenách priebehu a výsledkov jeho aktivít, výkonu, konania a prežívania vplyvom skúseností s prostredím. Pri termíne učenie hovoríme o procese motivovania, aktivovania, ul'ahčovania, usmerňovania a ovplyvňovania dejov učenia sa.

Samotné učenie zarad’ujeme medzi najdôležitejšie kognitívne procesy, vd'aka ktorým sa žiak d’alej rozvíja, môžeme povedat', že kognícia a kognitívne procesy sú neodmyslitel'nou súčast'ou učebného výkonu a osobnostného rozvoja žiaka. Kognitívne schopnosti zarad'ujeme k najdôležitejším mechanizmom zodpovedným za naše poznávanie. Označujú sa aj ako súbor psychických schopností, nevyhnutných k efektívnemu využívaniu vedomostí pri činnosti. Tento súbor psychických vlastností zahŕňa množstvo mentálnych, kognitívnych operácií (Kovalcikova, Ropovnik, 2012). Pod pojmom kognícia (lat. cognito) a kognitívne funkcie J. Duchovicova (2011) vymedzuje všetky mentálne schopnosti súvisiace $\mathrm{s}$ myslením a poznávaním. Kognitívne schopnosti sú zodpovedné za úspešnost' žiaka nielen v škole, ale aj v priebehu jeho života. Nachádzame ich vo všetkých oblastiach nášho života, pri myslení a iných psychických činnostiach. Okrem iného, tieto funkcie ovplyvňujú aj spôsob žiakovho spracovania predložených informácií, čo a ako si zapamätá, vytváranie predstáv, atd'. Úspech žiaka vo výchovno-vzdelávacom procese závisí od kvality rozvoja kognitívnych funkcií, ktorý žiak dosiahne učením sa. V širšom slova zmysle musíme kogníciu chápat' ako nadobúdanie, spracovávanie a nakoniec interpretovanie už získaných informácií. Často sa kognícia v užšom slova zmysle chápe ako spracovávanie nadobudnutých poznatkov bez akýchkol'vek emócií. Kognícia presahuje tento rámec.

Naučit' žiakov učit' sa je zložitý proces, ktorý vplýva na ich celoživotné vzdelávanie. Tento proces požaduje takú aplikáciu metód, prostredníctvom ktorých si žiak bude uvedomovat', čo je pri učení podstatné a čo naopak nie je podstatné, a aby aj vedel, čo mu pri učení pomáha. Postupne začne žiak rozumiet' javom v súvislostiach a hierarchiách (Kosova, 2001).

Ciel'om výchovno-vzdelávacieho procesu by mal byt' teda žiak, ktorý pozná nielen informácie, fakty, ale aj vzájomné vzt’ahy a súvislosti medzi nimi. Žiak, ktorý chce byt' úspešný, musí vediet', ako sa má učit' a musí ovládat' vhodné a efektívne stratégie učenia sa (Eberova, Uhlirova, 2005). Medzi takéto stratégie zarad'ujeme aj mentálne mapovanie.

\section{Mentálne mapovanie v edukačnom procese}

Metóda mentálneho mapovania nepatrí $\mathrm{v}$ našom školstve medzi bežné edukačné metódy na podporu a rozvoj učenia žiaka, zatial' čo v zahraničí, najmä v Amerike, tvorí pevnú súčast' didaktickej tradície. Mentálne mapy predstavujú grafickú reprezentáciu vedomostnej štruktúry žiaka z daného učiva, v ktorej body znázorňujú pojmy a spojnice, čiary, prestavujú vzt’ahy medzi jednotlivými pojmami. Podstata tejto metódy spočíva v osvojovaní vzájomných vzt’ahov medzi pojmami. Je to metóda učenia, testovania a zist'ovania vedomostí (Gunisova,Kozarova, 2016).

Pojmové mapovanie je procesom konštruovania pojmovej mapy, ktorá umožňuje žiakom názorne zobrazit' vzt'ahy medzi myšlienkami, pojmami, slovami, predstavami, ktoré majú v súvislosti s daným učivom alebo témou. Je zároveň prostriedkom spätnej väzby pre učitel'a. Pojmové mapy môžu slúžit' učitel'ovi ako informácia o doterajších poznatkoch žiaka, na ktoré by mal následne podl'a princípov zmysluplného učenia počas vyučovania učitel' nadviazat', ale tiež k zachyteniu prípadných miskoncepcií žiaka, pričom ciel'om je usilovat' o ich cielenú nápravu.

Pojmové mapovanie a jeho využitie v procese vzdelávania sme analyzovali v práci „Psychodidaktika“ (Duchovicova, 2011). Mentálna mapa je podl'a T. Buzana (2007) najdokonalejším nástrojom nášho mozgu, ktorý umožňuje informáciám dostat' sa do nášho mozgu, a to tvorivým a efektívnym spôsobom a rovnako tak ich dokáže $\mathrm{z}$

XLinguae, Volume 11, Issue 2, April 2018, ISSN 1337-8384, eISSN 2453-711X 
mozgu dostat' von. Pokial' človek pracuje s mentálnymi mapami, každá nová informácia, ktorú mozog prijme, sa automaticky prepojí so všetkými informáciami, ktoré tam už sú a prirodzeným spôsobom sa utriedia tak, aby mal ku ktorejkol'vek z informácií okamžitý prístup.

Tvorba myšlienkových máp prispieva $\mathrm{k}$ tréningu mozgu. Čim viac sa snaží jednotlivec svoj mozog rozvíjat', venovat' sa učeniu a cvičit' pamät', tým zložitejšie a prepracovanejšie myšlienkové štruktúry v mozgu vznikajú. T. Buzan (tamtiež) tvrdí, že pokial' medzi informáciami alebo predstavami nachádza jednotlivec asociácie, pomáhame svojmu mozgu vytvárat' spoje medzi nimi, a teda - mysliet'. Mentálne mapy zamestnávajú obe mozgové hemisféry, pretože sa v nich uplatňuje zobrazenie vizualizácia, farba a predstavivost' (pravá hemisféra) v kombinácii so slovami, číslami a logikou (l'avá hemisféra). Počas tvorby mentálnej mapy podnecujeme synergetické myslenie. Predstavy, ktoré sú zachytávané na mentálnej mape, sú navzájom prepojené a mozog môže vd'aka asociáciám uskutočňovat' také myšlienkové skoky, ktoré vedú $\mathrm{k}$ rýchlemu porozumeniu a k vyvolaniu bohatej predstavivosti. Logicky a organizovane prepojené informácie podporujú synergetický spôsob myslenia. Dané poznatky sú dôležité aj pre školské prostredie a oblast' vzdelávania. Všetky kl'účové pojmy alebo hlavné myšlienky, na ktoré sa má žiak sústredit', by mali byt' predkladané názorne (na tabuli, nákrese,...) a v hovorenom výklade je potrebné pojmy paralelne rozvádzat' do podrobností. Tým je umožnené pravej hemisfére spracovávat' to, čo vidí, zatial' čo l'avá hemisféra môže spracovávat' to, čo jej v podrobnejšej forme dodávajú slová. Spojenie týchto dvoch funkcií by malo prispiet' k účinnejšiemu učeniu a zapamätaniu látky.

Už neplatí, že proces myslenia funguje podl’a jednoduchého súčtového princípu, v ktorom každý nový údaj (myšlienka) je v mozgu iba d’alšou položkou. V synergetickom systéme platí vzorec, že 1 plus 1 sa rovná viac než dvom, teda celok je vždy väčší ako súčet jeho častí. Autor interpretuje daný princíp tak, že ak sa spojí nová informácia, ktorú sa chce človek naučit' s niečím čo už pozná, tak si nielenže lepšie zapamätá novú vec, ale hlbšie porozumie predstave už známej a mnohokrát dospeje i $\mathrm{k}$ širším poznatkom.

Ako uvádza J. Mares (2001), na jednej strane ide o prístupy vylepšenia vyučovacej činnosti učitel'a a na strane druhej, ak hovoríme o učebných stratégiách, ide o postupy zlepšenia činnosti žiakov pri výbere učiva, jeho zapamätávania, uskladňovania $\mathrm{v}$ pamäti a následného vybavenia v rámci intencií zmysluplného učenia.

Pojmové mapovanie má v oblasti vzdelávania viacero možností využitia. Pre učitel’a môže byt' užitočným prostriedkom pri plánovaní vyučovacieho procesu, vytvorení zmysluplnej štruktúry učiva, výber kl'účových pojmov a pod. M. Hubatka (2010) v tomto smere sumarizoval viacero praktických využití pojmového mapovania $\mathrm{v}$ oblasti vzdelávania. Pojmová mapa ako forma zápisu do zošita, v niektorých predmetoch je dokonca vhodnejšia než bežné poznámky žiakov, ako forma samostatnej alebo skupinovej práce, podklad $\mathrm{k}$ diskusii, metóda výučby porozumeniu textu, a tým pomôcka k rozvoju študijných schopností, výstup pre referát, prezentáciu, rozprávanie (osnova), plán projektu, činnosti, úlohy, hodiny (tvorba a následne realizácia plánu), pomôcka pre didaktickú prípravu učitel'a, plán projektu alebo akcie, príprava na hodinu, či ako plán alebo vízia do budúcnosti, systematizácia úloh a priorít a pod.

Hierarchická štruktúra máp značí, že najvšeobecnejšie pojmy sa nachádzajú v hornej časti mapy a viac špecifické (konkrétnejšie pojmy) sú usporiadané hierarchicky nižšie, preto je tendenciou týchto máp čítat' ich zhora nadol. Avšak nie je to pravidlom, pretože $\mathrm{v}$ súčasnosti už existujú rôzne formy mapovania, ktorým prislúcha viacero typov konkrétnych máp a nie všetky mapy vyjadrujú hierarchiu. (bližšie Duchovicova, 2013).

Učitel' môže viest' žiakov k tomu, aby v mape znázornili nielen primárne, ale aj sekundárne a terciálne väzby. Žiaci si pri tom môžu do svojej mapy zapisovat' aj stručné komentáre. Napriek tomu, že sa pojmová mapa pokladá za pomerne 
jednoduchú schému, je dôležité, aby pedagóg najskôr žiakov naučil mapy tvorit’ a používat' ich (Gunisova, Kozarova, 2016). Žiak môže prostredníctvom pojmovej mapy zobrazit' lineárne vzt'ahy, ktoré sú na rovnakej úrovni. Hierarchické vzt'ahy, ktoré predstavujú vzt’ahy nadradenosti a podradenosti alebo siete vzt’ahov, čo predstavuje systém vzt’ahov medzi pojmami (Gavora, 1999). Mentálne mapy sú založené na slobodnom myslení a uvažovaní nad problémom ako nad celkom. Najväčší pôžitok však prináša len motivovaným žiakom, ktorí sa pri učení opierajú o vizuálne spracovanie učiva, ktorí vedia učivo zanalyzovat' a dedukovat' vzt'ahy a majú vizuálnu predstavivost'. Paradoxne má táto stratégia v edukačnom procese primárneho a predškolského vzdelávania širší význam, ako sa vymedzuje v kontexte teórie zmysluplného učenia, pretože schopnosti podmieňujúce možnost' plnohodnotného využitia mentálnych máp sú tiež rozvíjatel'né. Potom sa rozsah pôvodných funkcií mentálneho mapovania pre žiakov nižších ročníkov značne rozširuje. Musíme hlbšie sledovat' potrebné dispozície, ktoré sa spájajú so zručnost'ou mapovania a zistíme, že ciel'avedomý rozvoj týchto dispozícií pri mapovaní v tejto vekovej kategórii žiakov definuje okrem pôvodných funkcií aj d’alšie funkcie. Schopnosti, ktoré sú u starších žiakov $\mathrm{v}$ procese mentálneho mapovania nevyhnutnost’ou, sa u mladších žiakov stávajú vd’aka mapovaniu obsahovými prvkami výchovy, ktoré sa prostredníctvom mapovania intenzívne rozvíjajú (Pupala, Osuska, 1997).

V kontexte uvedeného sme sa vpredmetnej štúdií zamerali na overenie vplyvu stratégie mentálneho mapovania na úroveň učebného výkonu v primárnom vzdelávaní.

\section{Ciele a dizajn výskumu}

Predmetom výskumu je stratégia mentálneho mapovania uplatňovaná v edukačnom procese v primárnom stupni vzdelávania a identifikácia jej vplyvu na učebný výkon žiakov $\mathrm{v}$ rovine faktických, konceptuálnych a procedurálnych poznatkov v témach vzdelávacích oblastí jazyk a komunikácia a príroda a spoločnost'.

Ciel'om výskumu bolo zistit' vplyv mentálneho mapovania vo vyučovaní vybraných tém (prírodovedne orientovaný obsah) na učebný výkon žiaka v primárnom vzdelávaní (3. a 4. ročník ZŠ).

Výskumný problém: Aký vplyv má využívanie stratégie mentálneho mapovania pri vyučovaní vybraných tém obsahu 3. a 4. ročníka ZŠ na kvalitu učebného výkonu v rovine faktických, konceptuálnych a procedurálnych poznatkov žiakov?

Predpokladali sme že:

- žiaci, u ktorých bola $\mathrm{v}$ rámci experimentálneho pôsobenia aplikovaná stratégia mentálneho mapovania vo vyučovaní vybraných tém dosiahnu významne vyšší učebný výkon v rovine faktických poznatkov ako žiaci, u ktorých stratégia uplatňovaná nebola,

- žiaci, u ktorých bola $\mathrm{v}$ rámci experimentálneho pôsobenia aplikovaná stratégia mentálneho mapovania vo vyučovaní vybraných tém dosiahnu významne vyšší učebný výkon $\mathrm{v}$ rovine konceptuálnych poznatkov ako žiaci, u ktorých stratégia uplatňovaná nebola,

- Žiaci, u ktorých bola $\mathrm{v}$ rámci experimentálneho pôsobenia aplikovaná stratégia mentálneho mapovania vo vyučovaní vybraných tém dosiahnu významne vyšší učebný výkon $\mathrm{v}$ rovine procedurálnych poznatkov ako žiaci, u ktorých stratégia uplatňovaná nebola.

Výskumná vzorka: Výskumnú vzorku tvorilo 100 žiakov 3. a 4. ročníka základných škôl. Výber vzorky bol zámerný s ciel'om zabezpečit' rovnocenné triedy vzhl'adom na vstupnú poznatkovú úroveň žiakov v triedach a učebné osnovy vo vzt’ahu k plánovanému zaradeniu vybraných tém obsahu primárneho vzdelávania. Rozdelenie skupín na experimentálne a kontrolné bolo náhodné. 
Výskumná metóda: Ako výskumnú metódu sme si zvolili experiment z toho hl’adiska, že táto metóda ako jediná z výskumných metód vie dokázat' kauzálne dôsledky pedagogického pôsobenia. Témy experimentálneho overovania pre aplikáciu stratégie mentálneho mapovania boli zo vzdelávacích oblastí jazyk a komunikácia a príroda a spoločnost'.

V rámci experimentálneho plánu sme použili pretes a posttest vypracovaný v zmysle revidovanej Bloomovej taxonómie (Anderson, Krathwohl, ed., 2001).

V experimente závislú premennú predstavoval učebný výkon žiaka, jeho úroveň nadobudnutých poznatkov. Nezávislou premennou bolo mentálne mapovanie. U kontrolnej a experimentálnej skupiny sme uskutočnením experimentu získali výsledky týkajúce sa faktických, konceptuálnych a procedurálnych poznatkov v závislosti od spôsobu prezentácie učiva s dôrazom na uplatnenie mentálnej mapy $\mathrm{v}$ edukačnom procese.

$\mathrm{Na}$ vyhodnotenie dát sme použili popisnú štatistiku, analýzu párového t- testu na priemernú hodnotu a analýzu diferenčného skóre (rozdielu skóre posttestu a pretestu), ktorá je zameraná na zmenu medzi pretestom a posttestom. Získane výsledky sme spracovali a analyzovali prostredníctvom počítačového programu Excel pre metódy popisnej štatistiky a taktiež štatistickým programom SPSS ver. 20.

\section{Analýza a interpretácia výsledkov}

\section{Vyhodnotenie vplyvu stratégie mentálneho mapovania na úroven̆ faktických vedomostí}

Predpokladali sme, že žiaci, u ktorých bola v rámci experimentálneho pôsobenia aplikovaná stratégia mentálneho mapovania vo vyučovaní vybraných tém dosiahnu významne vyšší učebný výkon v rovine faktických poznatkov ako žiaci, u ktorých stratégia uplatňovaná nebola.

V tabul'ke 1 sú obsiahnuté popisné štatistiky (priemer, minimum, maximum, smerodajná odchýlka, chyba priemernej hodnoty, medián) skóre pretestu a posttestu týkajúce sa faktických poznatkov, a to pre kontrolnú a experimentálnu triedu.

Tabul'ka 1: Popisná štatistika skóre pretestu a postestu - 3. roč.

\begin{tabular}{|l|c|c|c|c|c|c|c|}
\hline & $\mathbf{M}$ & $\mathbf{N}$ & SD & SEM & Min & Max & Medián \\
\hline pretest_Exp.sk & 3 & \multirow{2}{*}{16} & 1,506 & 0,376 & 1 & 6 & 3 \\
\cline { 1 - 5 } posttest_Exp.sk & 9,688 & & 1,991 & 0,498 & 11 & 13 & 10 \\
\hline pretest_Kontr.sk. & 5,059 & \multirow{2}{*}{17} & 1,853 & 0,449 & 2 & 8 & 5 \\
\cline { 1 - 5 } $\begin{array}{l}\text { posttest_Kontr. } \\
\text { sk. }\end{array}$ & 6,882 & & 1,965 & 0,477 & 3 & 9 & 7 \\
\hline
\end{tabular}

(M-priemerná hodnota skóre, $N$ - počet žiakov, $S D$ - smerodajná odchýlka, SEM chyba priemernej hodnoty)

Tabul'ka 2: Párový t- test na priemernú hodnotu

\begin{tabular}{|l|c|c|c|}
\hline & Df & t & P \\
\cline { 1 - 2 } pretest_Exp.sk & 15 & $-12,432$ & $<0,001$ \\
\cline { 1 - 1 } posttest_Exp.sk & & & $<0,001$ \\
\cline { 1 - 1 } pretest_Kontr.sk. & 16 & $-4,727$ & \\
\cline { 1 - 1 } posttest_Kontr. sk. & & & \\
\cline { 1 - 2 }
\end{tabular}

(df-počet stupňov volnosti, $t$ - hodnota testového kritéria, $p$ - p hodnota, po zaokrúhlení na tisicky)

Výsledky t- testu nám ukazujú, že rozdiely medzi pretestom a posttestom skupín v 3. roč. sú signifikantné, na hladine štatistickej významnosti $<0,05$.

Tabul'ka 3: Popisná štatistika skóre pretestu a posttestu - 4. roč.

\begin{tabular}{|l|c|c|c|c|c|c|c|}
\hline & M & N & SD & SEM & Min & Max & Medián \\
\hline pretest_Exp.sk & 4,355 & \multirow{2}{*}{31} & 2,042 & 0,367 & 1 & 9 & 4 \\
\cline { 1 - 5 } posttest_Exp.sk & 8 & & 1,807 & 0,325 & 4 & 11 & 8 \\
\hline
\end{tabular}




\begin{tabular}{|l|c|c|c|c|c|c|c|}
\hline pretest_Kontr.sk. & 5 & \multirow{2}{*}{36} & 1,852 & 0,309 & 2 & 9 & 5 \\
\cline { 1 - 4 } \cline { 5 - 8 } posttest_Kontr.sk. & 6,250 & & 1,888 & 0,315 & 3 & 10 & 6 \\
\hline
\end{tabular}

Tabul'ka 4: Párový t- test na priemernú hodnotu

\begin{tabular}{|l|c|c|c|}
\hline & df & t & p \\
\hline pretest_Exp.sk & 15 & $-12,195$ & $<0,001$ \\
\cline { 1 - 1 } posttest_Exp.sk & & & $<0,001$ \\
\cline { 1 - 1 } pretest_Kontr.sk. & 16 & $-4,005$ & \\
\hline posttest_Kontr.sk. & & & \\
\hline
\end{tabular}

(df-počet stupňov vol'nosti, $t$ - hodnota testového kritéria, $p-p$ hodnota, po zaokrúhleni na tisicky)

Výsledky t- testu nám ukazujú, že rozdiely medzi pretestom a posttestom oboch tried sú signifikantné, na hladine štatistickej významnosti $<0,05$.

Analýza diferenčného skóre v kontrolnej skupine a experimentálnej skupine faktické poznatky

Diferenčné skóre sme získali ako rozdiel dosiahnutého skóre $\mathrm{v}$ postteste a skóre $\mathrm{v}$ preteste.

Tabul'ka 5: Popisná štatistika diferenčného skóre v kontrolnej a experimentálnej skupine -3 . roč.

\begin{tabular}{|c|c|c|c|c|c|c|c|}
\hline & M & N & SD & SEM & Min & Max & Medián \\
\hline ES & 6,688 & 16 & 2,152 & 0,538 & 2 & 10 & 7 \\
\hline KS & 1,824 & 17 & 1,590 & 0,386 & -1 & 5 & 2 \\
\hline
\end{tabular}

Tabul'ka 6: Popisné štatistiky diferenčného skóre v kontrolnej a experimentálnej triede -4 . roč.

\begin{tabular}{|c|c|c|c|c|c|c|c|}
\hline & M & N & SD & SEM & Min & Max & Medián \\
\hline ES & 3,645 & 31 & 1,664 & 0,299 & 1 & 7 & 3 \\
\hline KS & 1,250 & 36 & 1,872 & 0,312 & -2 & 5 & 1 \\
\hline
\end{tabular}

Na posúdenie toho, či sa diferenčné skóre medzi KS a ES štatisticky významne líši sme použili dvojvýberový $\mathrm{t}$ - test pri rovnosti / nerovnosti rozptylov. Aby sme zistili rovnost' rozptylov sme použili $\mathrm{F}$ - test pre rovnost' rozptylov.

Tabul'ka 6: Výsledky F-testu diferenčného skóre pre rovnost' rozptylov - 3. roč.

\begin{tabular}{|c|c|c|c|c|}
\hline & $\mathbf{M}$ & $\mathbf{d f}$ & $\mathbf{F}$ & $\mathbf{p}$ \\
\hline ES & 6,688 & 31 & 1,830 & $<0,121$ \\
\hline KS & 1,824 & & & \\
\hline
\end{tabular}

(df-počet stupñov volnosti, $F$ - hodnota testového kritéria, $p-p$ hodnota, po zaokrúhlení na tisícky)

V tabul'ke 6 sú výsledky F- testu, ktorým testujeme rovnost' rozptylov v skupinách. Hodnota testovacieho kritéria $F$ je 1,830 a príslušná hodnota $p$ je $<0,121$, čo znamená, že na hladine štatistickej významnosti $<0,05$ nie je vo variabilite diferenčného skóre medzi ES a KS signifikantný rozdiel.

Tabul'ka 7: Výsledky F- testu diferenčného skóre pre rovnost' rozptylov - 4. roč.

\begin{tabular}{|c|c|c|c|c|}
\hline & $\mathbf{M}$ & df & $\mathbf{F}$ & $\mathbf{P}$ \\
\hline ES & 3,645 & 65 & 1,266 & $<0,257$ \\
\hline KS & 1,250 & & & \\
\hline
\end{tabular}

V tabul'ke 7 sú výsledky F- testu, ktorým testujeme rovnost' rozptylov v skupinách. Hodnota testovacieho kritéria $F$ je 1,266 a príslušná hodnota $p$ je $<0,257$, čo znamená, že na hladine štatistickej významnosti $<0,05$ nie je vo variabilite diferenčného skóre medzi ES a KS signifikantný rozdiel.

Tabul'ka 8: Výsledky $\mathrm{t}$ - testu diferenčného skóre pri rovnosti rozptylov - 3. roč.

\begin{tabular}{|c|c|c|c|c|}
\hline & $\mathbf{M}$ & $\mathbf{d f}$ & $\mathbf{T}$ & $\mathbf{p}$ \\
\hline ES & 6,688 & 31 & 7,416 & $<0,001$ \\
\hline
\end{tabular}

XLinguae, Volume 11, Issue 2, April 2018, ISSN 1337-8384, eISSN 2453-711X 


\begin{tabular}{|c|c|c|c|c|}
\hline KS & 1,824 & & & \\
\hline \multicolumn{5}{|c|}{$\begin{array}{l}\text { V tabul'ke } 8 \text { sú výsledky t- testu pri rovnosti rozptylov v skupinách. Hodnota } \\
\text { testovacieho kritéria t je } 7,416 \text {, príslušná p hodnota je }<0,001 \text {, čo znamená, že rozdiel } \\
\text { v diferenčnom skóre ES a KS je signifikantný na hladine štatistickej významnosti < } \\
0,05 \text {. } \\
\text { Tabul'ka 9: Výsledky t - testu diferenčného skóre pri rovnosti rozptylov - 4. roč. }\end{array}$} \\
\hline & $\mathbf{M}$ & df & $\mathbf{T}$ & $\mathbf{P}$ \\
\hline ES & 3,645 & 65 & 5,493 & $<0,001$ \\
\hline KS & 1,250 & & & \\
\hline
\end{tabular}

$\mathrm{V}$ tabul'ke 9 sú výsledky t- testu pri rovnosti rozptylov v skupinách. Hodnota testovacieho kritéria t je 7,416, príslušná p hodnota je $<0,001$, čo znamená, že rozdiel v diferenčnom skóre ES a KS je signifikantný na hladine štatistickej významnosti < 0,05 .

Na základe výsledkov experimentu konštatujeme, že náš predpoklad bol potvrdený. Žiaci, u ktorých bola v rámci experimentálneho pôsobenia aplikovaná stratégia mentálneho mapovania vo vyučovaní vybraných tém vzdelávacích oblastí jazyk a komunikácia a príroda a spoločnost' dosiahli významne vyšši učebný výkon $v$ rovine faktických poznatkov ako žiaci, u ktorých stratégia uplatňovaná nebola.

\section{Vyhodnotenie vplyvu stratégie mentálneho mapovania na úroveň konceptuálnych poznatkov}

Predpokladali sme, že žiaci, u ktorých bola v rámci experimentálneho pôsobenia aplikovaná stratégia mentálneho mapovania vo vyučovaní vybraných tém dosiahnu významne vyšší učebný výkon v rovine konceptuálnych poznatkov ako žiaci, u ktorých stratégia uplatňovaná nebola,

V tabul'ke 10 sú obsiahnuté popisné štatistiky (priemer, minimum, maximum, smerodajná odchýlka, chyba priemernej hodnoty, medián) skóre pretestu a posttestu týkajúce sa konceptuálnych poznatkov, a to pre kontrolnú a experimentálnu triedu.

Tabul'ka 10: Popisná štatistika skóre pretestu a posttestu - 3. roč.

\begin{tabular}{|c|c|c|c|c|c|c|c|}
\hline & $\mathbf{M}$ & $\mathbf{N}$ & SD & SEM & Min & Max & Medián \\
\hline pretest_Exp.sk & 2,438 & \multirow[t]{2}{*}{16} & 1,031 & 0,258 & 0 & 4 & 2,5 \\
\hline posttest_Exp.sk & 9,563 & & 1,750 & 0,438 & 3 & 10 & 10 \\
\hline pretest_Kontr. sk. & 3,706 & \multirow[t]{2}{*}{17} & 1,213 & 0,294 & 2 & 6 & 4 \\
\hline posttest_Kontr.sk. & 5,529 & & 1,419 & 0,344 & 2 & 7 & 6 \\
\hline
\end{tabular}

Tabul'ka 11: Párový t- test na priemernú hodnotu -3 . roč.

\begin{tabular}{|l|c|c|c|}
\hline & df & t & P \\
\cline { 1 - 1 } pretest_Exp.sk & 15 & -20.954 & $<0,001$ \\
\cline { 1 - 1 } posttest_Exp.sk & & & $<0,001$ \\
\cline { 1 - 1 } pretest_Kontr.sk. & 16 & $-4,980$ & \\
\hline posttest_Kontr.sk. & & & \\
\hline
\end{tabular}

Výsledky t- testu nám ukazujú, že rozdiely medzi pretestom a posttestom oboch tried sú signifikantné, na hladine štatistickej významnosti $<0,05$.

Tabul'ka 12: Popisná štatistika skóre pretestu a posttestu - 4. roč.

\begin{tabular}{|l|c|c|c|c|c|c|c|}
\hline & M & N & SD & SEM & Min & Max & Medián \\
\hline pretest_Exp.sk & 2,387 & \multirow{3}{*}{31} & 1,430 & 0,257 & 0 & 6 & 2 \\
\cline { 1 - 6 } posttest_Exp.sk & 6,097 & & 1,868 & 0,336 & 2 & 10 & 6 \\
\hline pretest_Kontr.sk. & 1,806 & \multirow{3}{*}{36} & 1,327 & 0,221 & 0 & 5 & 2 \\
\cline { 1 - 5 } & & & 1,699 & 0,283 & 0 & 6 & 3 \\
\hline
\end{tabular}

Tabul'ka 13: Párový t- test na priemernú hodnotu - 4. roč.

\begin{tabular}{|l|c|c|c|}
\hline & df & t & P \\
\hline pretest_Exp.sk & 30 & $-11,291$ & $<0,001$ \\
\hline
\end{tabular}




\begin{tabular}{|l|l|l|l|}
\hline posttest_Exp.sk & & & \\
\cline { 1 - 2 } pretest_Kontr.sk. & 35 & $-6,121$ & $<0,001$ \\
\cline { 1 - 1 } posttest_Kontr.sk. & & & \\
\hline
\end{tabular}

Výsledky t- testu nám ukazujú, že rozdiely medzi pretestom a posttestom oboch tried sú signifikantné, na hladine štatistickej významnosti $<0,05$.

Analýza diferenčného skóre v kontrolnej skupine a experimentálnej skupine konceptuálne poznatky

Tabul'ka 14: Popisná štatistika diferenčného skóre v kontrolnej a experimentálnej triede -3 .roč.

\begin{tabular}{|c|c|c|c|c|c|c|c|}
\hline & M & N & SD & SEM & Min & Max & Medián \\
\hline ES & 7,125 & 16 & 1,360 & 0,340 & 3 & 9 & 7 \\
\hline KS & 1,824 & 17 & 1,510 & 0,366 & -1 & 4 & 2 \\
\hline
\end{tabular}

Tabul'ka 15: Popisná štatistika diferenčného skóre v kontrolnej a experimentálnej triede - 4.roč.

\begin{tabular}{|c|c|c|c|c|c|c|c|}
\hline & M & N & SD & SEM & Min & Max & Medián \\
\hline ES & 3,710 & 31 & 1,829 & 0,329 & 0 & 7 & 4 \\
\hline KS & 1,389 & 36 & 1,337 & 0,223 & -1 & 4 & 1 \\
\hline
\end{tabular}

Na posúdenie toho, či sa diferenčné skóre medzi KS a ES štatistický významne líši sme použili dvojvýberový t- test pri rovnosti / nerovnosti rozptylov. Aby sme zistili rovnost' rozptylov použijeme $\mathrm{F}$ - test pre rovnost' rozptylov.

Tabul'ka 16: Výsledky F- testu diferenčného skóre pre rovnost' rozptylov - 3. roč.

\begin{tabular}{|c|c|c|c|c|}
\hline & M & df & F & p \\
\hline ES & 7,125 & 31 & 1,232 & $<0,345$ \\
\hline KS & 1,824 & & & \\
\hline
\end{tabular}

V tabul'ke 16 sú výsledky F- testu, ktorým testujeme rovnost' rozptylov v skupinách. Hodnota testovacieho kritéria $F$ je 1,232 a príslušná $p$ hodnota je $<0,345$, čo znamená, že na hladine štatistickej významnosti $<0,05$ nie je vo variabilite diferenčného skóre medzi ES a KS signifikantný rozdiel.

Tabul'ka 17: Výsledky F- testu diferenčného skóre pre rovnost' rozptylov - 4. roč.

\begin{tabular}{|c|c|c|c|c|}
\hline & $\mathbf{M}$ & $\mathbf{d f}$ & $\mathbf{F}$ & $\mathbf{p}$ \\
\hline ES & 3,710 & 65 & 0,534 & $<0,038$ \\
\hline KS & 1,389 & & & \\
\hline
\end{tabular}

V tabul'ke 17 sú výsledky F- testu, ktorým testujeme rovnost' rozptylov v skupinách. Hodnota testovacieho kritéria $F$ je 0,534 a príslušná hodnota $p$ je $<0,038$, čo znamená, že na hladine štatistickej významnosti $<0,05$ je vo variabilite diferenčného skóre medzi ES a KS signifikantný rozdiel.

Tabul'ka 18: Výsledky t - testu diferenčného skóre pri rovnosti rozptylov - 3. roč.

\begin{tabular}{|c|c|c|c|c|}
\hline & $\mathbf{M}$ & $\mathbf{d f}$ & $\mathbf{t}$ & $\mathbf{P}$ \\
\hline $\mathbf{E S}$ & 7,125 & 31 & 10,575 & $<0,001$ \\
\hline KS & 1,824 & & & \\
\hline
\end{tabular}

Hodnota testovacieho kritéria t je 10,575, príslušná p hodnota je $<0,001$, čo znamená, že rozdiel $\mathrm{v}$ diferenčnom skóre je signifikantný na hladine štatistickej významnosti $<0,05$.

Tabul'ka 19: Výsledky $\mathrm{t}$ - testu diferenčného skóre pri nerovnosti rozptylov - 4. roč.

\begin{tabular}{|c|c|c|c|c|}
\hline & $\mathbf{M}$ & $\mathbf{d f}$ & $\mathbf{t}$ & $\mathbf{P}$ \\
\hline ES & 3,710 & 54 & 5,846 & $<0,001$ \\
\hline KS & 1,389 & & & \\
\hline
\end{tabular}

V tabul'ke 19 sú výsledky t- testu pri rovnosti rozptylov v skupinách. Hodnota testovacieho kritéria t je 5,846, príslušná p hodnota je $<0,001$, čo znamená, že rozdiel 
v diferenčnom skóre ES a KS je signifikantný na hladine štatistickej významnosti < 0,05 .

Na základe výsledkov experimentu konštatujeme, že náš predpoklad bol potvrdený. Žiaci, u ktorých bola v rámci experimentálneho pôsobenia aplikovaná stratégia mentálneho mapovania vo vyučovaní vybraných tém vzdelávacích oblastí jazyk a komunikácia a príroda a spoločnost' dosiahli významne vyšší učebný výkon $v$ rovine konceptuálnych poznatkov ako žiaci, u ktorých stratégia uplatn̆ovaná nebola.

\section{Vyhodnotenie vplyvu stratégie mentálneho mapovania na úroveň procedurálnych poznatkov}

Predpokladali sme, že žiaci, u ktorých bola v rámci experimentálneho pôsobenia aplikovaná stratégia mentálneho mapovania vo vyučovaní vybraných tém dosiahnu významne vyšší učebný výkon v rovine procedurálnych poznatkov ako žiaci, u ktorých stratégia uplatňovaná nebola.

V tabul'ke 20 sú obsiahnuté popisné štatistiky (priemer, minimum, maximum, smerodajná odchýlka, chyba priemernej hodnoty, medián) skóre pretestu a posttestu týkajúce sa procedurálnych poznatkov, a to pre kontrolnú a experimentálnu triedu.

Tabul'ka 20: Popisná štatistika skóre pretestu a posttestu - 3. roč.

\begin{tabular}{|l|c|c|c|c|c|c|c|}
\hline & $\mathbf{M}$ & $\mathbf{N}$ & SD & SEM & Min & Max & Medián \\
\hline pretest_Exp.sk & 2,438 & \multirow{2}{*}{16} & 1,153 & 0,288 & 0 & 4 & 2,5 \\
\cline { 1 - 6 } posttest_Exp.sk & 5 & & 1,549 & 0,387 & 1 & 6 & 6 \\
\hline pretest_Kontr.sk. & 0,529 & \multirow{2}{*}{17} & 0,874 & 0,212 & 0 & 3 & 0 \\
\cline { 1 - 5 } \cline { 5 - 8 } posttest_Kontr.sk. & 0,941 & & 0,827 & 0,201 & 0 & 3 & 1 \\
\hline
\end{tabular}

Tabul'ka 21: Párový t- test na priemernú hodnotu -3 . roč.

\begin{tabular}{|l|c|c|c|}
\hline & df & t & P \\
\cline { 1 - 1 } pretest_Exp.sk & 15 & $-6,622$ & $<0,001$ \\
\cline { 1 - 1 } posttest_Exp.sk & & & $<0,001$ \\
\cline { 1 - 1 } pretest_Kontr.sk. & 16 & $-2,135$ & \\
\hline
\end{tabular}

Výsledky t- testu nám ukazujú, že rozdiely medzi pretestom a posttestom oboch tried sú signifikantné, na hladine štatistickej významnosti $<0,05$.

Tabul'ka 22: Popisná štatistika skóre pretestu a posttestu - 4. roč.

\begin{tabular}{|l|c|c|c|c|c|c|c|}
\hline & M & N & SD & SEM & Min & Max & Medián \\
\hline pretest_Exp.sk & 0,936 & \multirow{3}{*}{31} & 0,629 & 0,113 & 0 & 2 & 1 \\
\cline { 1 - 5 } posttest_Exp.sk & 2,323 & & 0,541 & 0,097 & 1 & 3 & 2 \\
\hline pretest_Kontr.sk. & 1,083 & \multirow{3}{*}{36} & 0,691 & 0,115 & 0 & 3 & 1 \\
\hline posttest_Kontr.sk. & 2,167 & & 0,561 & 0,093 & 1 & 3 & 2 \\
\hline
\end{tabular}

Tabul'ka 23: Párový t- test na priemernú hodnotu

\begin{tabular}{|l|c|c|c|}
\hline & df & T & p \\
\cline { 1 - 1 } pretest_Exp.sk & 30 & $-10,154$ & $<0,001$ \\
\cline { 1 - 1 } posttest_Exp.sk & & & $<0,001$ \\
\cline { 1 - 1 } pretest_Kontr.sk. & 35 & $-8,442$ & \\
\hline posttest_Kontr.sk. & & & \\
\hline
\end{tabular}

Výsledky t- testu nám ukazujú, že rozdiely medzi pretestom a posttestom oboch tried sú signifikantné, na hladine štatistickej významnosti $<0,05$.

Analýza diferenčného skóre v kontrolnej skupine a experimentálnej skupine procedurálne poznatky 
Tabul'ka 24: Popisná štatistika diferenčného skóre v kontrolnej a experimentálnej triede -3 . roč.

\begin{tabular}{|c|c|c|c|c|c|c|c|}
\hline & M & N & SD & SEM & Min & Max & Medián \\
\hline ES & 2,563 & 16 & 1,548 & 0,387 & -1 & 5 & 2,5 \\
\hline KS & 0,412 & 17 & 0,795 & 0,193 & -1 & 2 & 0 \\
\hline
\end{tabular}

Tabul'ka 25: Popisná štatistika diferenčného skóre v kontrolnej a experimentálnej triede -4 . roč.

\begin{tabular}{|c|c|c|c|c|c|c|c|}
\hline & M & N & SD & SEM & Min & Max & Medián \\
\hline ES & 1,387 & 31 & 0,760 & 0,137 & 0 & 3 & 1 \\
\hline KS & 1,083 & 36 & 0,769 & 0,128 & 0 & 3 & 1 \\
\hline
\end{tabular}

Na posúdenie toho, či sa diferenčné skóre medzi kontrolnej a experimentálnej skupiny štatistický významne líši sme použili dvojvýberový t - test pri rovnosti / nerovnosti rozptylov. Aby sme zistili rovnost' rozptylov použijeme F - test pre rovnost' rozptylov.

Tabul'ka 26: Výsledky F- testu diferenčného skóre pre rovnost' rozptylov - 3. roč.

\begin{tabular}{|c|c|c|c|c|}
\hline & $\mathbf{M}$ & $\mathbf{d f}$ & $\mathbf{F}$ & $\mathbf{P}$ \\
\hline $\mathbf{E S}$ & 2,563 & 31 & 3,789 & $<0,006$ \\
\hline KS & 0,412 & & & \\
\hline
\end{tabular}

V tabul'ke 26 sú výsledky F- testu, ktorým testujeme rovnost' rozptylov v skupinách. Hodnota testovacieho kritéria $F$ je 3,789 a príslušná $p$ hodnota je $<0,006$, čo znamená, že na hladine štatistickej významnosti $<0,05$ je vo variabilite diferenčného skóre medzi ES a KS signifikantný rozdiel.

Tabul'ka 27: Výsledky F- testu diferenčného skóre pre rovnost' rozptylov - 4. roč.

\begin{tabular}{|c|c|c|c|c|}
\hline & $\mathbf{M}$ & df & $\mathbf{F}$ & $\mathbf{P}$ \\
\hline ES & 1,387 & 65 & 1,025 & $<0,476$ \\
\hline KS & 1,083 & & & \\
\hline
\end{tabular}

V tabul'ke 27 sú výsledky F- testu, ktorým testujeme rovnost' rozptylov v skupinách. Hodnota testovacieho kritéria $F$ je 1,025 a príslušná hodnota $p$ je $<0,476$, čo znamená, že na hladine štatistickej významnosti $<0,05$ nie je vo variabilite diferenčného skóre medzi ES a KS signifikantný rozdiel.

Tabul'ka 28: Výsledky $\mathrm{t}$ - testu diferenčného skóre pri nerovnosti rozptylov - 3. roč.

\begin{tabular}{|c|c|c|c|c|}
\hline & $\mathbf{M}$ & $\mathbf{d f}$ & $\mathbf{t}$ & $\mathbf{P}$ \\
\hline ES & 2,563 & 22 & 4,974 & $<0,001$ \\
\hline KS & 0,412 & & & \\
\hline
\end{tabular}

Hodnota testovacieho kritéria t je 4,974, príslušná p hodnota je $<0,001$, čo znamená, že rozdiel v diferenčnom skóre je signifikantný na hladine štatistickej významnosti < 0,05 .

Tabul'ka č.29: Výsledky t - testu diferenčného skóre pri rovnosti rozptylov - 4. roč.

\begin{tabular}{|c|c|c|c|c|}
\hline & $\mathbf{M}$ & $\mathbf{d f}$ & $\mathbf{t}$ & $\mathbf{P}$ \\
\hline $\mathbf{E S}$ & 1,387 & 65 & 1,619 & $<0,055$ \\
\hline KS & 1,083 & & & \\
\hline
\end{tabular}

V tabul'ke 29 sú výsledky t- testu pri rovnosti rozptylov v skupinách. Hodnota testovacieho kritéria t je 1,619 , príslušná p hodnota je $<0,055$, čo znamená, že rozdiel $\mathrm{v}$ diferenčnom skóre ES a KS nie je signifikantný na hladine štatistickej významnosti $<0,05$.

Na základe výsledkov experimentu konštatujeme, že náš predpoklad nebol potvrdený. Žiaci, u ktorých bola v rámci experimentálneho pôsobenia aplikovaná stratégia mentálneho mapovania vo vyučovaní vybraných tém vzdelávacích oblastí jazyk a komunikácia a príroda a spoločnost' dosiahli významne vyšši učebný výkon v rovine procesuálnych poznatkov ako žiaci, u ktorých stratégia uplatňovaná nebola, ale len v 3. ročníku. Vo 4. ročníku neboli výsledky štatisticky významné preto hypotézu zamietame.

XLinguae, Volume 11, Issue 2, April 2018, ISSN 1337-8384, eISSN 2453-711X 


\section{Záver a diskusia}

Psychodidaktický výskum má potenciál vyvolat' u učitel’ov množstvo otázok vedúcich k zmenám ich pohl'adu na vyučovanie, je predpokladom pre rozširovanie pohl'adu na kontext súvislostí vyučovacieho procesu, sprostredkovania informácií, ale predovšetkým rozvíjania čiastkových kognitívnych funkcií učiacich sa. Psychodidaktické spojenie je podporované i vzdelávacou politikou v kontexte nového edukačného prístupu, orientovaného na rozvoj kompetencií autonómnej osobnosti v procese celoživotného vzdelávania. V našom psychodidakticky orientovanom výskume sme sa zamerali na overenie vplyvu stratégie mentálneho mapovania v primárnom vzdelávaní na úroveň učebného výkonu vo faktoroch faktické, konceptuálne a procedurálne poznatky. Zistili sme, že žiaci, u ktorých bola v rámci experimentálneho pôsobenia aplikovaná stratégia mentálneho mapovania vo vyučovaní vybraných tém vzdelávacích oblastí jazyk a komunikácia a príroda a spoločnost' dosiahli významne vy̌šsi učebný výkon v rovine faktických poznatkov, konceptuálnych poznatkov a v rovine procesuálnych poznatkov (s výnimkou experimentálnej skupiny 4. ročníka) ako žiaci, u ktorých stratégia uplatňovaná nebola. Vo 4. ročníku neboli výsledky štatisticky významné preto sme hypotézu zamietli.

Pri celkovom zhodnotení konštatujeme, že stratégia mentálneho mapovania má pozitívny vplyv na učebný výkon žiaka v primárnom stupni vzdelávania. Obdobné výsledky sme zaznamenali aj v overovaní stratégie v sekundárnom stupni vzdelávania (Duchovicova, 2013). Po zadaní pojmových máp žiakom a ich grafickom vyhodnotení sme zistili, že žiaci, ktorým je učivo prezentované nelineárne, dosahujú vy̌̌šiu úroveň odborných poznatkov vo vybraných vyučovacích predmetoch než žiaci, ktorým je učivo prezentované lineárne.

Vzhl'adom k daným zisteniam odporúčame učitel'om použivat' stratégiu mentálneho mapovania vo vyučovacom procese, pretože umožňujú žiakom názorne usporadúvat' jednotlivé prvky učiva a prepájat' doterajšie poznatky žiakov s novými informáciami. Proces tvorby pojmových máp podporuje zmysluplné učenie žiakov a pre učitel'a predstavuje spätnú väzbu o tom, nakol'ko žiaci danému učivu rozumejú. Dôležitým faktorom je $\mathrm{v}$ tomto smere aj potreba zácviku žiakov do techniky mapovania. Odporúčame prechádzat' $\mathrm{z}$ myšlienkového mapovania postupne $\mathrm{k}$ pojmovému mapovaniu. Pri zložitejších typoch pojmových máp a v náročných témach je vhodné umožnit' žiakom tvorit' úvodné mapy, ktoré môžu postupne reorganizovat' a dopracovat' sa až k mapám finálnym. Následné porovnanie pôvodných pojmových máp s mapami finálnymi môže byt' prínosom tak pre žiaka ako aj učitel'a, pretože jednotlivé mapy zaznamenávajú posuny, resp. zmeny, ktoré nastali v poznatkovom systéme žiaka v priebehu vyučovania a žiakovho učenia. Sme toho názoru, že pokial' má byt' práca s pojmovými mapami na vyučovaní naozaj efektívna a zmysluplná, dodatočný rozhovor so žiakmi predstavuje ich dôležitú súčast'. Preto učitel'om odporúčame pri práci s mapami rozhovor so žiakmi, pretože každá mapa žiaka je subjektívna a nemožno ju hodnotit' ako nesprávnu. Odzrkadl'uje žiakovo chápanie jednotlivých prvkov učiva, prepojenost' doteraz získaných informácií, skúseností, osvojených a zapamätaných poznatkov (vedomostí), ale tiež nových informácií, ktoré len majú byt' osvojené a zaradené do celkového poznatkového systému žiaka.

Táto práca bola podporovaná Agentúrou na podporu výskumu a vývoja na základe Zmluvy č. APVV-15-0368.

\section{Bibliographic references}

ANDERSON, L.W. - KRATHWOHL, P. 2001. A Taxonomy for Learning, Teaching a Assesing of Educational Objectives. New York: Longman, 
BOJARE, I. - SKRINDA, A. 2016. Transformation of the system of values of autonomous learning for English acquisition in blended E-studies for adults: A holistic fractal model. In: Journal of Teacher Education for Sustainability, vol. 18, n. 2, pp. 119-134. ISSN 1691-4147.

BUZAN, T. 2007. Mentalni mapovani. Praha: Portal, 2007. 168 p. ISBN 978-807367-200-3.

DUCHOVICOVA, J. 2011. Kognitivna edukacia a sprostredkovane ucenie. In: Kolektiv autorov. 2011. Vybrane kapitoly z didaktiky pedagogiky a socialnej pedagogiky. Nitra: PF UKF, 2011. 373 p. ISBN 978-80-8094-857-3.

DUCHOVICOVA, J. 2013. Psychodidaktika v kontextoch sprostredkovaneho a zmysluplného ucenia. In Duchovicova, J. - Skoda, J. a kol. 2013. Psychodidakticke pojeti kurikularniho a mediacniho kontextu edukace. Usti nad Labem: Univerzita Jana Evangelisty Purkyne, 2013. pp. 8 - 76. ISBN 978-80-7414-658-9.

DUCHOVICOVA, J. - PETROVA,G. 2017. Psychodidakticke kompetencie ucitela a moznosti ich rozvijania prostrednictvom pedagogickej praxe $\mathrm{v}$ konkretnych odborovych didaktikach. In Studia scientifica Fakulltatis Paedagogicae. Ruzmberok : Verbum, pp. 88- 101, ISSN 1336-2232.

EBEROVA, J. - UHLIROVA, M. 2005. Jak se uspesne ucit. In: Induktivne a deduktivne pristupy v matematike, 2005, pp. 58 - 61. [21.3.2017]. Available online: https://www.google.sk/url?sa=t\&rct=j\&q=\&esrc=s\&source=web\&cd=1\&cad=rja\&ua $\mathrm{ct}=8 \&$ ved=0ahUKEwjr5Yicn4jTAhWC2RoKHa3SC1wQFggYMAA\&url=http\%3A $\% 2 \mathrm{~F} \% 2 \mathrm{Fpdf}$.truni.sk\%2Fdownload\%3Fzbornik\%2Fsmolenice\%2Feberovauhlizova.p df\&usg=AFQjCNEp9W1CPzbYt2DuE9q0CHBe8uKw\&bvm=bv.151325232,d.bGs GAVORA, P. 1999. Aki su moji ziaci?: Pedagogicka diagnostika ziaka. Bratislava: Praca, 1999. 239 p. ISBN 80-7094-335-1.

GUNISOVA, D. - KOZAROVA, N. 2016. Pojmove mapy v teorii a praxi. Nitra: ForPress Nitrianske tlaciarne s.r.o, 2016. 174 p. ISBN 978-80-558-1075-1.

HUBATKA, M. 2010. Myslenkove mapy. Priklad z praxe. In Moderne vyucovani, vol. $\quad \mathrm{X}, \quad$ n. 1 [cit. 2013-06-03]. Available: http://digi.modernivyucovani.cz/media/magazine/pdf/2010_1_leden.pdf. ISSN 12116858.

KOSOVA , B., 2001. Skola orientovana na dieta. In: Pedagogicke rozhlady, ISSN 1335-0404, 2001, vol. 10, n. 2, pp. 8 - 13.

KOVALCIKOVA, I. - ROPOVNIK, I. 2012. Exekutivne fungovanie ako predpoklad schopnosti ucit sa. In Pedagogicke rozhlady, ISSN 1335-0404, 2012, n. 5, pp. 1-5.

LOFSTROM, E. 2008. Student teachers' experiences of their studies in educational science and psychology. In: Journal of Teacher Education for Sustainability, vol. 10, pp. 56-67. ISSN 1691-4147.

MARES, J. 2001. Strukturovanie uciva. In CAP, J. - MARES, J. Psychologie pro ucitele. Praha: Portal. 655 p. ISBN 80- 7178-463-X.

PUPALA, B. - OSUSKA, L. 1997. Stimulacia ucenia deti pomocou pojmoveho mapovania. In Pedagogicka revue, vol. XLIX, n. 5-6, pp. 210-218, ISSN 1335-1982.

SALITE, I. - DRELINGA, E. - ILISKO, D. - OLEHNOVICA, E. - ZARINA, S. 2016. Sustainability from the transdisciplinary perspective: An action research strategy for continuing education program development. In: Journal of Teacher Education for Sustainability, vol. 18, n. 2, pp. 135-152. ISSN 1691-4147.

STASULANE, A. 2017. Factors Determining Children and Young People's Wellbeing at School. In: Journal of Teacher Education for Sustainability, vol. 19, n. 2, pp. 165-179. ISSN 1691-4147.

SVEC, S. 2011. Inovativne pristupy v didaktike. K zdarnej obnove vzdelavania. Bratislava: UK, 2011. 186 p. ISBN 978-80-223-3221-7. 
Words: 5310

Characters: 35354 (19,64 standard pages)

doc. PaedDr. Jana Duchovičová, PhD.

Mgr. Rebeka Štefánia Koleňáková

Department of Pedagogy, Faculty of Education

Constantine the Philosopher University in Nitra,

Dražovská cesta 4, 94974 Nitra

Slovakia

jduchovicova@ukf.sk

rebeka.stefania.kolenakova@ukf.sk 